\title{
Serological pattern of anti-HBc alone infers occult hepatitis B virus infection in high-risk individuals in Iran
}

\author{
Amitis Ramezani ${ }^{1}$, Mohammad Banifazl ${ }^{2}$, Ali Eslamifar ${ }^{1}$, Arezoo Aghakhani ${ }^{1}$ \\ ${ }^{1}$ Clinical Research Department, Pasteur Institute of Iran, Tehran, Iran \\ ${ }^{2}$ Iranian society for support of patients with infectious diseases, Tehran, Iran
}

\begin{abstract}
Introduction: Anti-hepatitis B core antibody (Anti-HBc) alone is defined as the presence of anti-HBc in the absence of $\mathrm{HBsAg}$ and anti-HBs. The significance of this serological pattern as a predicting factor for occult hepatitis B virus (HBV) infection remains largely unknown. This study aimed to assess the significance of anti-HBc alone in predicting occult HBV infection in high-risk and low-risk individuals.

Methodology: A total of 926 individuals were enrolled in this study, including 289 hemodialysis (HD) and 106 HIV-infected patients who were considered as a high-risk group and 531 blood donors who were considered as low-risk. HBsAg, anti-HBs, anti-HBc were tested in all subjects. The presence of HBV-DNA was determined quantitatively in patients with anti-HBc alone by real-time PCR.

Results: Of the 395 high-risk patients, 40 cases (10.13\%) had anti-HBc alone, while 11 subjects (2.07\%) out of 531 blood donors had anti$\mathrm{HBc}$ alone. HBV-DNA was detected in 12 out of 40 (30\%) high-risk patients and none of the blood donors with anti-HBc alone.

Conclusion: Our study showed that the serological pattern of anti-HBc alone could reflect occult HBV infection in high risk cases but did not presume occult HBV infection in low-risk individuals.
\end{abstract}

Key words: hepatitis B core antibody (anti-HBc) alone; occult hepatitis B virus (HBV) infection

J Infect Dev Ctries 2010; 4(10):658-661.

(Received 07 December 2009 - Accepted 18 May 2010)

Copyright (C) 2010 Ramezani et al. This is an open-access article distributed under the Creative Commons Attribution License, which permits unrestricted use, distribution, and reproduction in any medium, provided the original work is properly cited.

\section{Introduction}

Presence of hepatitis B core antibody (anti-HBc) in the absence of hepatitis B surface antigen (HBsAg) and hepatitis B surface antibody (anti-HBs) is defined as anti-HBc alone [1]. This serological pattern is observed in $10 \%-20 \%$ of individuals from areas of low endemicity for HBV [1], including Iran[2]. In one study on 4,930 subjects in Iran, $5.13 \%$ were positive for only anti-HBc, without any detectable HBsAg [3].

The significance of this serological pattern is unclear. It may reflect past infection with $\mathrm{HBV}$, after which anti-HBs either did not develop [4] or decreased to an undetectable level [1]. Also, this serological pattern can be observed in the window phase of a resolving case of acute hepatitis B. Finally, it may represent occult chronic HBV infection, with levels of the HBsAg below the limits of detection [5].

Occult HBV infection is characterized by the presence of HBV infection with undetectable HBsAg
[6]. The clinical implications of occult HBV infection involve different clinical aspects. First, occult HBV infection harbors potential risk of $\mathrm{HBV}$ transmission through blood transfusion, hemodialysis, and organ transplantation. Second, it may serve as the cause of cryptogenic liver disease, contributing to acute exacerbation of chronic hepatitis B. Third, it is associated with the development of hepatocellular carcinoma. Fourth, it may affect disease progression and treatment response of chronic hepatitis C [6].

The significance of anti-HBc alone as a predicting factor for occult $\mathrm{HBV}$ infection remains unknown. The aim of this study was to assess the significance of this serological pattern in predicting occult HBV infection in high-risk and low-risk individuals.

\section{Methodology}

\section{Patients}


In this study 926 individuals, including 289 hemodialysis (HD) and 106 HIV infected patients as high-risk group and 531 voluntary blood donors as low-risk group, were enrolled. The samples were collected from five dialysis units, Blood Transfusion Organization and Iranian Research Center for HIV/AIDS in Tehran, Iran, between January and December 2008. This project was approved by the Iranian Society for Support of Patients with Infectious Diseases ethics committee and informed consent was obtained from patients prior to their enrollment.

HD patients were considered as a high-risk group because of possible HBV acquisition through frequent blood transfusions and medical procedures that accompany bleeding, and HIV-infected patients were classified as a high-risk group because of highrisk behaviors such as injection drug use. Voluntary Blood donors were considered as low-risk due to the generally low opportunities for transmission possibilities and blood exchange events in the general population when compared to the high-risk group.

\section{Blood samples}

Blood samples were collected through venipuncture from all cases and transferred for analysis to the laboratory of the clinical research department of the Pasteur Institute of Iran. Blood samples were centrifuged and plasmas were separated. Plasma samples were stored at $-80^{\circ} \mathrm{C}$. All samples were tested for $\mathrm{HBsAg}$, anti-HBs, hepatitis C antibody (anti-HCV), and anti-HBc by enzymelinked immunosorbent assay (ELISA). The commercial enzyme immunoassay kits used were as follows: HBsAg and anti-HBs (Hepanosticka Biomerieux, Boxtel, The Netherlands: sensitivity < $0.1 \mathrm{ng} / \mathrm{ml}$ and specificity $99.95 \%$ for HBsAg and sensitivity $<2 \mathrm{mIu} / \mathrm{ml}$ and specificity $99 \%$ for anti$\mathrm{HBs}$ ); anti-HBc (Dia.Pro Diagnostic BioProbes, Milan, Italy: sensitivity and specificity $99.7 \%$ ); and anti-HCV (Biorad, Segrate, Italy: sensitivity 99.6\% and specificity $99.8 \%$ ).

Human immunodeficiency virus antibody (antiHIV) was determined by ELISA (MP Biomedicals, Illkirch, France), with positive tests confirmed by Western blot assay (Diaplus, San Francisco, USA).

HBV-DNA was extracted using High Pure Viral Nucleic Acid kit (Roche Diagnostics GmbH, Mannheim, Germany). The HBV core region was amplified and then HBV-DNA was determined quantitatively by real-time PCR using the artus HBV RG PCR kit (QIAGEN, Hamburg, Germany) on the
Rotor-Gene 3000 real-time thermal cycler (Corbett Research, Sydney, Australia).

Statistical analysis

The Chi-square and t2-tests were used with the SPSS 16 Package program for statistical analysis (Chicago, IL, USA). Data are presented as mean \pm SD or, when indicated, as an absolute number and percentage. A $P$ value of $<0.05$ was considered significant. The $95 \%$ confidence interval $(95 \% \mathrm{CI})$ was calculated.

\section{Results}

This study included 926 individuals. Of these, 289 hemodialysis (HD) and 106 HIV-infected patients were considered a high-risk group and 531 voluntary blood donors a low-risk group. Characteristics of high-risk and low-risk groups are shown in Table 1.

Of the 395 high-risk patients, 40 (18 HD and 22 HIV-infected) cases $(10.13 \%, 95 \%$ CI, 7.1\%-13.1\%) had anti-HBc alone. Eleven of the 531 blood donors (2.07\%, 95\% CI, $0.8 \%-3.2 \%)$ had anti-HBc alone. There was not any significant difference between individuals with and without anti-HBc alone regarding age $(P=0.22)$, sex $(P=0.16)$ and antiHCV positivity $(P=0.59)$.

HBV-DNA was detected in 12 out of 40 patients $(30 \%, 95 \%$ CI, $15.8 \%-44.2 \%)$ in the high-risk group and none of the blood donors (low-risk group) with anti-HBc alone. There was not any significant difference between HBV-DNA positive and negative subjects regarding age $(P=0.15)$, sex $(P=0.23)$ and anti-HCV positivity $(P=0.61)$.

Table 1. Characteristics of high-risk and low-risk individuals

\begin{tabular}{|c|c|c|c|}
\hline $\begin{array}{c}\text { Cases } \\
\text { Characteristic }\end{array}$ & $\begin{array}{c}\text { Hemodialysis } \\
\text { patients } \\
(\mathrm{n}=289)\end{array}$ & $\begin{array}{c}\text { HIV } \\
\text { infected } \\
\text { patients } \\
(\mathrm{n}=106)\end{array}$ & $\begin{array}{c}\text { Blood } \\
\text { donors } \\
(\mathrm{n}=531)\end{array}$ \\
\hline Sex (M/F) & $174 / 115$ & $79 / 27$ & $494 / 37$ \\
\hline Age (year) & $55 \pm 16$ & $36.6 \pm 9.6$ & $\begin{array}{c}36 \pm \\
10.18\end{array}$ \\
\hline $\begin{array}{c}\text { Anti-HCV } \\
(+)\end{array}$ & $3.1 \%$ & $67 \%$ & $0.2 \%$ \\
\hline $\begin{array}{c}\text { anti-HBc } \\
\text { alone (+) }\end{array}$ & $18(6.2 \%)$ & $22(20.75 \%)$ & $11(2.07 \%)$ \\
\hline $\begin{array}{c}\text { DNA } \\
\text { positive anti- } \\
\text { HBc alone }\end{array}$ & $9 / 18(50 \%)$ & $3 / 22(13.6 \%)$ & $0 / 11(0 \%)$ \\
\hline
\end{tabular}

Data are indicated as mean and number $(\%)$; anti-HBc, hepatitis B core antibody; anti-HCV, hepatitis $\mathrm{C}$ antibody 


\section{Discussion}

In this study the significance of the serological pattern of anti-HBc alone in predicting occult HBV infection in high-risk and low-risk individuals was assessed. HBV-DNA was detectable in $30 \%$ of the high-risk cases and none of the low-risk subjects with anti-HBc alone. Our survey showed that occult HBV infection was relatively common in high-risk patients with anti-HBc alone regardless of age, sex and anti$\mathrm{HCV}$ positivity, but not frequent in low-risk individuals.

In published studies the prevalence of occult $\mathrm{HBV}$ infection in HIV-seropositive populations ranged from $0 \%$ to $10 \%$ by standard PCR assays [79] and from $35 \%-89 \%$ by more sensitive methods [10,11]. Santos et al. [12] reported that $35 \%$ of HIVinfected patients had the anti-HBc only pattern and the prevalence of occult $\mathrm{HBV}$ infection in them was $10 \%$. The prevalence of occult HBV infection in renal dialysis patients ranges between $0 \%$ and $58 \%$ in published reports [13-15]. In the studies by Dueymes et al., [15] the detection rate of HBV-DNA in HD patients was $13.9 \%$ with an anti-HBc seropositivity of $64.7 \%$. The percentage of samples containing HBV-DNA from either blood donors or the general population ranges between $0 \%$ to $7.7 \%$ in areas where the HBV prevalence is low [16,17], and in areas of higher HBV infection prevalence, such as Ghana, the frequency of DNA positive anti-HBc alone cases increases to $12.7 \%$ [18]. Kaminski et al. [19] reported that $20.5 \%$ of HBsAg-negative blood donors had the anti-HBc only pattern and the prevalence of occult HBV infection in them was $0 \%$. These discrepancies in the rate of occult HBV infection may reflect the diverse prevalence of HBV infection in different countries, the sensitivity of the various molecular biology techniques used, and the size and virological features of the patient groups.

Some studies showed association between HCV and occult HBV infection [20]. However, due to the limited number of $\mathrm{HCV}$-infected subjects in the current study, a conclusion cannot be reached regarding the association of occult $\mathrm{HBV}$ infection and HCV serostatus.

The failure of demographic findings to suggest the presence of occult $\mathrm{HBV}$ is not unexpected. Detectable HBV-DNA in serum was not predicted by demographic parameters [21] and occult infections have been described in both high- and lowprevalence regions and various ethnic populations with no age or gender predilections [22] like those in our study.
In conclusion, HBV-DNA was detectable in 30\% of the high-risk cases and none of the low-risk subjects with anti-HBc alone. While our study showed that detection of anti-HBc alone could reflect occult HBV infection in high-risk groups, and hence screening of these patients is useful in preventing of HBV transmission, this serological pattern did not predict occult HBV infection in low-risk individuals.

\section{Acknowledgement}

The authors are grateful to Iranian society for support patients with infectious diseases for financial support of this study.

\section{References}

1. Grob P, Jilg W, Bornhak H, Grob P, Jilg W, Bornhak H, Gerken G, Gerlich W, Günther S, Hess G, Hüdig H, Kitchen A, Margolis H, Michel G, Trepo C, Will H, Zanetti A, Mushahwar I (2000) Serological pattern "anti-HBc alone": report on a workshop. J Med Virol 62: 450-455.

2. Alavian SM, Fallahian F, Bagheri Lankarani K (2007) The changing epidemiology of viral hepatitis B in Iran. J Gastrointestin Liver Dis 16:403-406.

3. Merat S, Malekzadeh R, Rezvan H, Khatibian M (2000) Hepatitis B in Iran. Arch Iran Med 3: 192-201.

4. Lok AS, Lai CL, Wu PC (1988) Prevalence of isolated antibody to hepatitis B core antigen in an area endemic for hepatitis B virus infection: implications in hepatitis B vaccination programs. Hepatology 8: 766-770.

5. Gandhi RT, Wurcel A, Lee H, Gandhi RT, Wurcel A, Lee H, McGovern B, Boczanowski M, Gerwin R, Corcoran CP, Szczepiorkowski Z, Toner S, Cohen DE, Sax PE, Ukomadu C (2003) Isolated antibody to hepatitis B core antigen in human immunodeficiency virus type-1-infected individuals. Clin Infect Dis 36: 1602-1605.

6. $\mathrm{Hu}$ KQ (2002) Occult hepatitis B virus infection and its clinical implications. J Viral Hepat. 9: 243-257.

7. Neau D, Winnock M, Jouvencel AC, Neau D, Winnock M, Jouvencel AC, Faure M, Castéra L, Legrand E, Lacoste D, Ragnaud JM, Dupon M, Fleury H, Lafon ME, Dabis F, Groupe d'Epidemiologie Clinique du SIDA en Aquitaine (2005) Occult hepatitis B virus infection in HIV-infected patients with isolated antibodies to hepatitis B core antigen: Aquitaine cohort, 2002-2003. Clin Infect Dis 40: 750-753.

8. Nunez M, Rios P, Perez-Olmeda M, Soriano V (2002) Lack of 'occult' hepatitis B virus infection in HIV-infected patients. AIDS 16: 2099-2101.

9. Shire NJ, Rouster SD, Rajicic N, Sherman KE (2004) Occult hepatitis B in HIV-infected patients. J Acquir Immune Defic Syndr 36: 869-875.

10. Hofer M, Joller-Jemelka HI, Grob PJ, Luthy R, Opravil M (1998) Frequent chronic hepatitis B virus infection in HIVinfected patients positive for antibody to hepatitis B core antigen only. Swiss HIV Cohort Study. Eur J Clin Microbiol Infect Dis 17: 6-13.

11. Piroth L, Binquet C, Vergne M, Piroth L, Binquet C, Vergne M, Minello A, Livry C, Bour JB, Buisson M, Duong M, Grappin M, Portier H, Chavanet P (2002) The evolution of hepatitis B virus serological patterns and the clinical relevance of isolated antibodies to hepatitis B core antigen in HIV infected patients. J Hepatol 36: 681-686. 
12. Santos EA, Yoshida CF, Rolla VC, Santos EA, Yoshida CF, Rolla VC, Mendes JM, Vieira IF, Arabe J, Gomes SA (2003) Frequent occult hepatitis B virus infection in patients infected with human immunodeficiency virus type 1. Eur $\mathbf{J}$ Clin Microbiol Infect Dis 22: 92-98.

13. Oesterreicher C, Hammer J, Koch U, Oesterreicher C, Hammer J, Koch U, Pfeffel F, Sunder-Plassmann G, Petermann D, Müller C (1995) HBV and HCV genome in peripheral blood mononuclear cells in patients undergoing chronic hemodialysis. Kidney Int 48: 1967-1971.

14. Minuk GY, Sun DF, Greenberg R, Minuk GY, Sun DF, Greenberg R, Zhang M, Hawkins K, Uhanova J, Gutkin A, Bernstein K, Giulivi A, Osiowy C (2004) Occult hepatitis B virus infection in a North American adult hemodialysis patient population. Hepatology. 40: 1072-1077.

15. Dueymes JM, Bodenes-Dueymes M, Mahe JL, Herman B (1993) Detection of hepatitis B viral DNA by polymerase chain reaction in dialysis patients. Kidney Int 43: S161-6.

16. Henning H, Puchta I, Luhm J, Henning H, Puchta I, Luhm J, Schlenke P, Goerg S, Kirchner H (2002) Frequency and load of hepatitis B virus DNA in first-time blood donors with antibodies to hepatitis B core antigen. Blood 100: 26372641.

17. Kleinman SH, Kuhns MC, Todd DS, Kleinman SH, Kuhns MC, Todd DS, Glynn SA, McNamara A, DiMarco A, Busch MP (2003) Retrovirus Epidemiology Donor Study: Frequency of HBV-DNA detection in US blood donors testing positive for the presence of anti-HBc: implication for transfusion transmission and donor screening. Transfusion 43: 696-704.

18. Allain JP, Candotti D, Soldan K, Allain JP, Candotti D, Soldan K, Sarkodie F, Phelps B, Giachetti C, Shyamala V,
Yeboah F, Anokwa M, Owusu-Ofori S, Opare-Sem O (2003) The risk of hepatitis B virus infection by transfusion in Kumasi, Ghana. Blood 101: 2419-2425

19. Kaminski G, Alnaqdy A, Al-Belushi I, Nograles J, AlDhahry SH (2006) Evidence of occult hepatitis B virus infection among Omani blood donors: a preliminary study. Med Princ Pract 15: 368-372.

20. Fabrizi F, Messa PG, Lunghi G, Fabrizi F, Messa PG, Lunghi G, Aucella F, Bisegna S, Mangano S, Villa M, Barbisoni F, Rusconi E, Martin P (2005) Occult hepatitis B virus infection in dialysis patients: a multicentre survey. Aliment Pharmacol Ther 21: 1341-1347.

21. Yildirim M, Yavuz MT, Ozdemir D, Behçet M, Sencan I (2008) High rate of hepatitis B virus DNA positivity in anti$\mathrm{HBc}$ only-positive patients. Mikrobiyol Bul 42: 535-536.

22. Fabrizi F, Lunghi G, Alongi G, Fabrizi F, Lunghi G, Alongi G, Aucella F, Barbisoni F, Bisegna S, Corghi E, Faranna P, Mangano S, Romei-Longhena G, Martin P (2008) Kinetics of hepatitis B virus load and haemodialysis: a prospective study. J Viral Hepat 15: 917-921.

\section{Corresponding author}

Arezoo Aghakhani

Clinical Research Department

Pasteur Institute of Iran

No 69, Pasteur Ave., Tehran, 13164, Iran

Tel: +982166465147; Fax: +982166465147

Email: araghakhani@hotmail.com

Conflict of interests: No conflict of interests is declared. 